\title{
Cerebrospinal fluid choline in extrapyramidal disorders ${ }^{1}$
}

\author{
S-M. AQUILONIUS ${ }^{2}$, B. NYSTRÖM, J. SCHUBERTH, AND A. SUNDWALL \\ From the Research Institute of National Defence, Department 1, Sundbyberg; Department of Neuro- \\ surgery, University of Uppsala; Psychiatric Research Center, Ulleråker Hospital, University of \\ Uppsala, and Department of Pharmacology, University of Uppsala, Sweden
}

SUMMARY Cerebrospinal fluid from patients with Parkinson's disease and Huntington's chore has been investigated with regard to the concentration of choline. In Parkinson's disease the choline् concentration of lumbar spinal fluid was not different from that of a control group, nor was i related to medication, duration of illness, or severity of symptoms. A comparison between choline i $\vec{p}$ ventricular cerebrospinal fluid from patients with Parkinson's disease and with intention tremo $\overrightarrow{\vec{L}}$ showed no significant differences. Patients with Huntington's chorea had a lower concentration o choline in lumbar spinal fluid as compared with a control group. The results are discussed in relatio to the possible sources of cerebrospinal fluid choline.

The possibilities of studying the function of neurotransmitter systems in the human brain are limited and our knowledge is to a great extent based on analogies from animal experiments. In the last years, however, biochemical analyses of the monoamine transmitters noradrenaline, dopamine, and 5-hydroxytryptamine in brain material obtained at necropsy (Ehringer and Hornykiewicz, 1960) and of their metabolites in the cerebrospinal fluid (CSF) (Guldberg, Turner, Hanieh, Ashcroft, Crawford, Perry, and Gillingham, 1967; Johansson and Roos 1967) have given new approaches to the study of these transmitters in man.

The cholinergic transmitter acetylcholine (ACh), however, cannot be investigated in brain material from necropsy due to a rapid postmortem change of the ACh concentration. Further, investigations on $\mathrm{ACh}$ in the CSF have so far been rather inconclusive and its occurrence as a normal constituent of CSF has been a matter of controversy (Schain, 1960; Duvoisin and Dettbarn, 1967). The cholinergic precursor and end-product choline $(\mathrm{Ch})$ is, on the other hand, detectable in the CSF in a fairly low con-

\footnotetext{
1 A preliminary report of this work was presented at the XXVth Scandinavian Pharmacological Meeting, Copenhagen 1971.

2 Present address: Department of Neurology, University of Uppsala, Sweden.
}

centration. We thus raised the question whet a change in the concentration of $\mathrm{Ch}$ in humb CSF could reflect an altered cholinergic acting in the central nervous system.

In Parkinson's disease, evidence points to cholinergic dominance in the striatum due te decreased dopaminergic inhibition on choline neurones in this region (Calne, 1970). Fn Huntington's chorea, on the other hand, it was recently suggested that a cholinergic hypofunction might exist in striatal mechanisms regulating motor activity (Aquilonius and Sjöström, 1971) As Parkinson's disease and Huntington's chore thus could be in contrasting relationship re garding central cholinergic activity, we found if interesting to study the concentration of $\mathrm{Ch}$ in CSF of patients suffering from these twe disorders.

\section{METHODS}

SELECTION OF PATIENTS AND CONTROLS The diagno ses of the patients suffering from Parkinson's disease were considered unmistakable in the departments of neurology or neurosurgery. In one group of $1 \%$ patients with Parkinson's disease, lumbar punctures (2-3 ml.) were performed with the patients on their. usual anticholinergic medication (orphenadrinos hydrochloride and/or benzhexol chloride). In 10 
patients lumbar punctures were also undertaken, either before treatment had started or after withdrawal of drugs for five days. The patients exhibited more pronounced symptoms without anticholinergic therapy, which could also be documented by objective measurement of rigidity and tremor by a method earlier described (Aquilonius and Tiselius, 1969). Another group of five patients with Parkinson's disease who were on anticholinergic medication had tremor as the dominating symptom. In these patients lumbar and ventricular CSF was taken at ventriculography ${ }^{1}$ before stereotaxic surgery. A third group of patients were on stationary L-dopa treatment when lumbar punctures were performed.

Lumbar CSF from 17 patients suffering from Huntington's chorea was analysed. These people were inpatients at different clinics and mental hospitals in Sweden. They had typical heredity and were all examined by one of the authors who considered the diagnosis to be well established. It was not feasible to withdraw drug therapy (mainly phenothiazines and/or haloperidol) in the majority of patients with Huntington's chorea. In three cases at our own clinic, drug therapy was withdrawn for five days before lumbar puncture.

Duration of illness has been estimated from the date of appearance of clinical symptoms as given in the case history. The patients with Huntington's chorea were crudely classified as one group with mild to moderate and one group with severe dementia. Patients unable to comprehend easy instructions and permitting no verbal contact were referred to the severe group.

The control group consisted of 19 persons with no sign or history of neurological disease; three of the controls were healthy volunteers, while the rest were patients submitted to the Department of General Surgery for the diagnoses shown in Table 1 . The age distribution of the controls corresponded satisfactorily with that of the patients (Fig. 5). Ventricular CSF concentration of $\mathrm{Ch}$ was further determined in five patients with intention tremor of idiopathic origin undergoing ventriculography and in 16 patients with different diagnoses (Table 2) undergoing operation in the Department of Neurosurgery. The general anaesthetics used in the latter patients are shown in Table 2. Ventricular size was rated as normal or increased, based on the encephalographic findings, and CSF pressure was graded as normal or increased at ventricular puncture.

DETERMINATION OF CH IN CSF Choline was determined by an enzymatic method (Jönsson, Schuberth,

1 Patients were awake at ventriculography, having been given a premedication of triethylperazine $(8.6 \mathrm{mg})$ as suppository and an analgesic containing caffeine $(0.2 \mathrm{~g})$, phenacetin $(0.6 \mathrm{~g})$ orally $30 \mathrm{~min}$ before the examination.
TABLE 1

CSF CHOLINE CONCENTRATION IN EXTRAPYRAMIDAL DISEASE

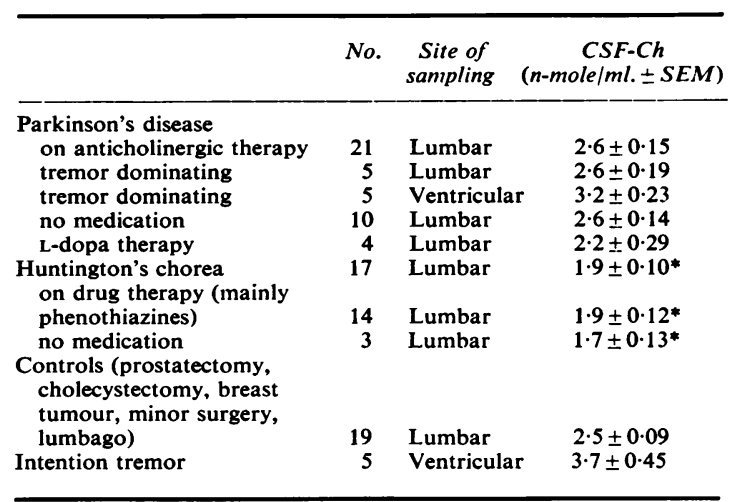

* Significantly different from controls $(P<0.01)$.

and Sundwall, 1969; Schuberth and Sundwall, 1971), based on the choline acetyltransferase catalysed formation of labelled ACh from labelled acetyl-CoA and the $\mathrm{Ch}$ in the sample. The CSF samples were stored frozen until analysed. All samples showing macroscopic blood contamination were discarded. A microscopic blood contamination was not related to the $\mathrm{Ch}$ value in the CSF (Fig. 1). All Ch analyses were performed as at least duplicates on different days and $\mathrm{Ch}$ concentrations are given as means of those determinations.

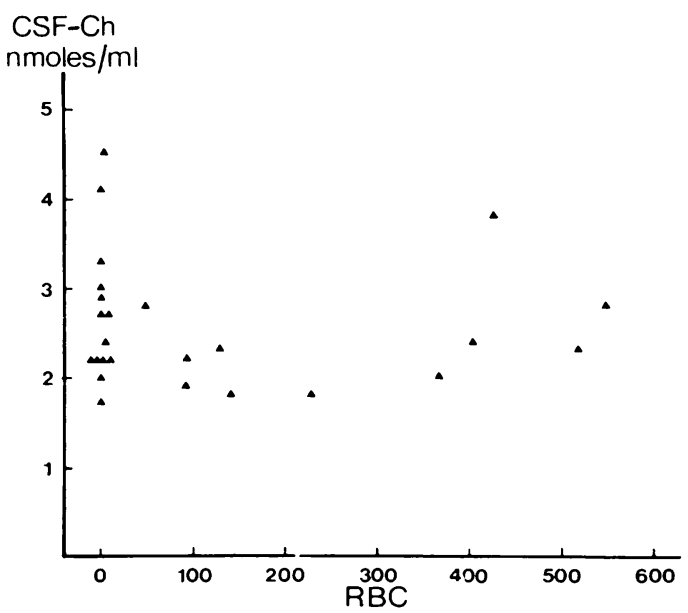

FIG. 1. Ch concentration (n-mole/ml.) and microscopic blood contamination in 24 samples of lumbar $C S F .\left(R B C=\right.$ red blood count per $\left.\mathrm{mm}^{3}.\right)$ 
TABLE 2

CHOLINE CONCENTRATION OF VENTRICULAR CSF IN DIFFERENT BRAIN DISORDERS

\begin{tabular}{|c|c|c|c|c|c|c|}
\hline Patient & $\begin{array}{l}\text { Age } \\
(y r)\end{array}$ & Diagnosis & $\begin{array}{c}C S F \\
\text { pressure }\end{array}$ & Ventricular size & General anaesthetic & $\begin{array}{c}C h \\
(n-m o l e / m l .)\end{array}$ \\
\hline $\begin{array}{l}\text { M.P. } \\
\text { C.G. } \\
\text { E.A. } \\
\text { L.P. } \\
\text { A.M. } \\
\text { K.K. } \\
\text { R.W. } \\
\text { S.N. } \\
\text { A.N. } \\
\text { B.N. } \\
\text { I.H. }\end{array}$ & $\begin{array}{r}2 \\
4 \\
6 \\
19 \\
1 \\
24 \\
18 \\
35 \\
61 \\
42 \\
57\end{array}$ & $\begin{array}{l}\text { Medulloblastoma } \\
\text { Medulloblastoma } \\
\text { Medulloblastoma } \\
\text { Medulloblastoma } \\
\text { Dandy Walker cyst } \\
\text { Dandy Walker cyst } \\
\text { Cerebellar tumour } \\
\text { Cerebellar tumour } \\
\text { Brain-stem tumour } \\
\text { Craniopharyngioma } \\
\text { Inflammatory expansive } \\
\text { process }\end{array}$ & $\begin{array}{l}\text { Increased } \\
\text { Increased } \\
\text { Increased } \\
\text { Increased } \\
\text { Increased } \\
\text { Increased } \\
\text { Increased } \\
\text { Increased } \\
\text { Increased } \\
\text { Increased } \\
\text { Increased }\end{array}$ & $\begin{array}{l}\text { Slightly increased } \\
\text { Increased } \\
\text { Increased } \\
\text { Increased } \\
\text { Increased } \\
\text { Increased } \\
\text { Slightly increased } \\
\text { Abnormal } \\
\text { Slightly increased } \\
\text { Slightly increased } \\
\text { Normal }\end{array}$ & $\begin{array}{l}\mathrm{O}_{2}+\mathrm{N}_{2} \mathrm{O}+\text { halothane } \\
\mathrm{O}_{2}+\mathrm{N}_{2} \mathrm{O}+\text { halothane } \\
\mathrm{O}_{2}+\mathrm{N}_{2} \mathrm{O}+\text { halothane } \\
\mathrm{O}_{2}+\mathrm{N}_{2} \mathrm{O}+\text { halothane } \\
\mathrm{O}_{2}+\mathrm{N}_{2} \mathrm{O}+\text { halothane } \\
\mathrm{O}_{2}+\mathrm{N}_{2} \mathrm{O}+\text { halothane } \\
\mathrm{O}_{2}+\mathrm{N}_{2} \mathrm{O}+\text { halothane } \\
\mathrm{O}_{2}+\mathrm{N}_{2} \mathrm{O}+\text { methoxyflurane } \\
\mathrm{O}_{2}+\mathrm{N}_{2} \mathrm{O}+\text { methoxyflurane } \\
\mathrm{O}_{2}+\mathrm{N}_{2} \mathrm{O}+\text { halothane } \\
\mathrm{O}_{2}+\mathrm{N}_{2} \mathrm{O}\end{array}$ & $\begin{array}{l}1 \cdot 9 \\
5 \cdot 3 \\
2 \cdot 1 \\
4 \cdot 0 \\
6 \cdot 5 \\
5 \cdot 0 \\
3 \cdot 4 \\
4 \cdot 8 \\
4 \cdot 6 \\
5 \cdot 5 \\
7 \cdot 0\end{array}$ \\
\hline $\begin{array}{l}\text { E.A. } \\
\text { E.K. } \\
\text { S.J. } \\
\text { G.D. } \\
\text { A.B. }\end{array}$ & $\begin{array}{l}53 \\
54 \\
61 \\
60 \\
66\end{array}$ & $\begin{array}{l}\text { Cerebral glioma } \\
\text { Cerebral glioma } \\
\text { Cerebral meningioma } \\
\text { Hydrocephalus } \\
\text { Cerebral atrophy }\end{array}$ & $\begin{array}{l}\text { Increased } \\
\text { Increased } \\
\text { Increased } \\
\text { Normal } \\
\text { Normal }\end{array}$ & $\begin{array}{l}\text { Normal } \\
\text { Increased } \\
\text { Increased } \\
\text { Slightly increased } \\
\text { Normal }\end{array}$ & $\begin{array}{l}\mathrm{O}_{2}+\mathrm{N}_{2} \mathrm{O} \\
\mathrm{O}_{2}+\mathrm{N}_{2} \mathrm{O} \\
\mathrm{O}_{2}+\mathrm{N}_{2} \mathrm{O}+\text { halothane } \\
\mathrm{O}_{2}+\mathrm{N}_{2} \mathrm{O}+\text { halothane } \\
\mathrm{O}_{2}+\mathrm{N}_{2} \mathrm{O}+\text { methoxyflurane }\end{array}$ & $\begin{array}{l}3 \cdot 0 \\
2 \cdot 4 \\
3 \cdot 0 \\
4 \cdot 3 \\
3 \cdot 5\end{array}$ \\
\hline
\end{tabular}

\section{RESULTS}

The mean values of CSF Ch concentration of the different groups are summarized in Table 1. As seen from this Table there is no difference in the Ch concentration of lumbar CSF between the control group and the patients suffering from Parkinson's disease-neither with nor without anticholinergic therapy. There seemed to be no relationship between individual $\mathrm{CSF}$ Ch values

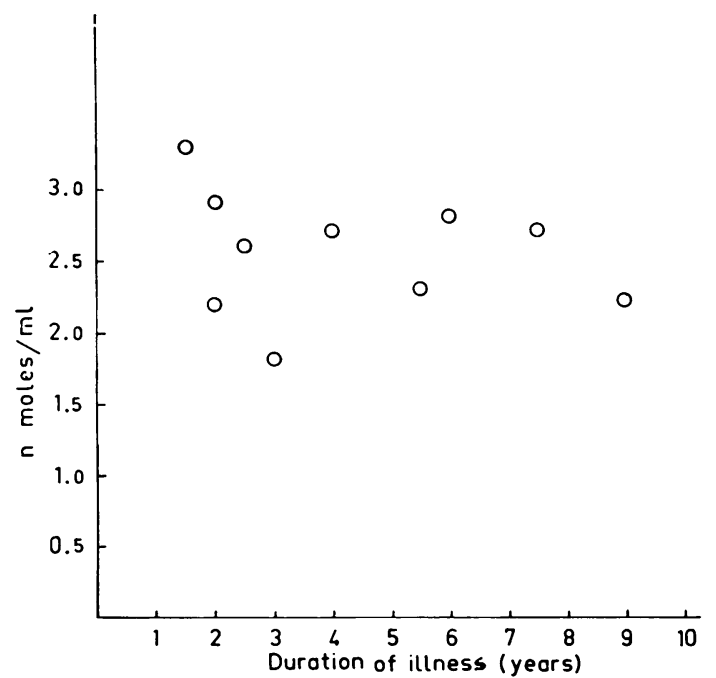

FIG. 2. Lumbar CSF Ch concentration (n-mole/ml.) and duration of illness in 10 patients with Parkinson's disease. No drug therapy.

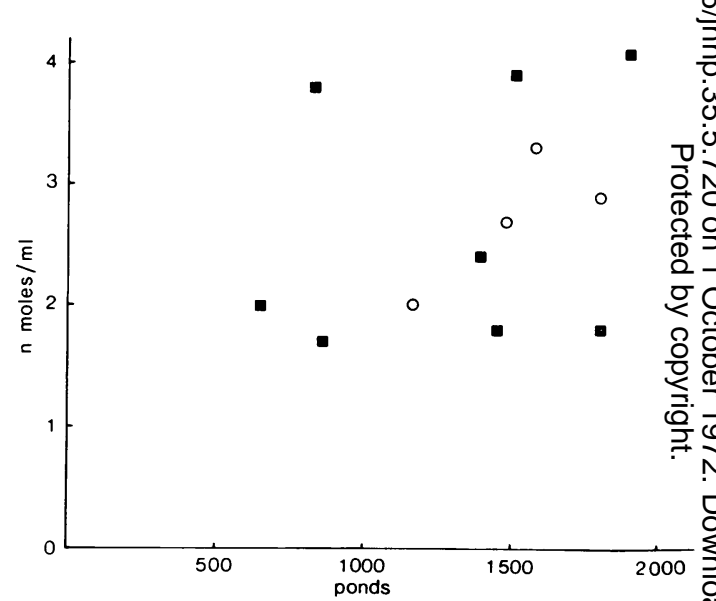

FIG. 3. Lumbar CSF Ch concentration (n-mole $/ \mathrm{ml}$.) and rigidity objectively measured. Rigidity in ponds measured as described by Aquilonius and Tiseliusō (1969). Rigidity values of right and left side are added. $\bigcirc=$ no medication, $\mathbf{Q}=$ anticholinergic therapy.

in the Parkinsonism group and duration of illness (Fig. 2) or rigidity objectively measured in some of the patients (Fig. 3). The five patientso with tremor dominating showed the same mean value as the rest of the material. A somewhat lower mean value than in the controls was found in the group on L-dopa treatment (Table 1).

In the patients with Huntington's chorea, on the other hand, the mean $\mathrm{Ch}$ concentration of 


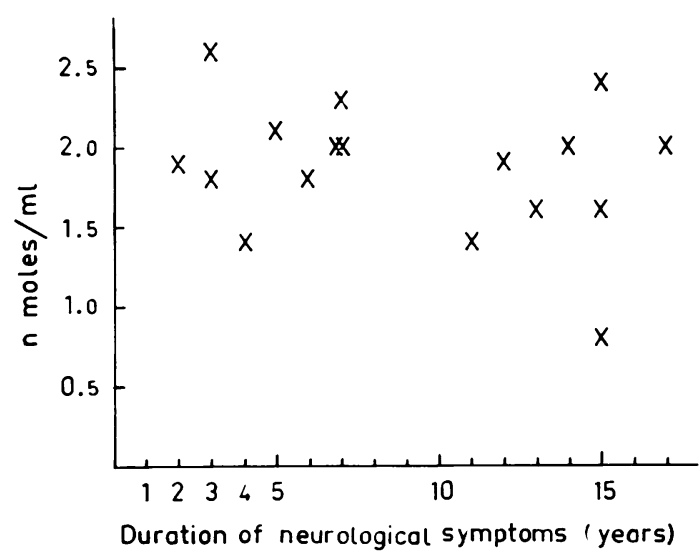

FIG. 4. Lumbar CSF Ch concentration (n-mole/ml.) and duration of illness in 17 patients suffering from Huntington's chorea.

lumbar CSF was significantly lower than that in the controls and in the patients with Parkinson's disease. This is true for patients with and without drug therapy (Table 1). No correlation existed between lumbar CSF $\mathrm{Ch}$ concentration and duration of illness (Fig. 4). The same $\mathrm{Ch}$ concentration was found in patients with severe $(n=6)$ and moderate $(n=11)$ dementia $(1 \cdot 8 \pm$ 0.23 and $1.9 \pm 0.10 \mathrm{n}$-mole $/ \mathrm{ml}$ respectively). Although a highly significant difference was found between the mean lumbar CFS Ch con-

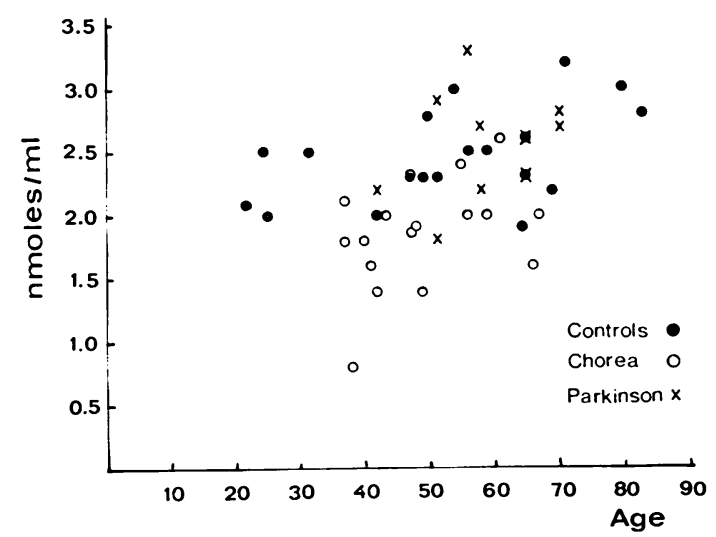

FIG. 5. Lumbar CSF Ch concentration (n-mole/ml.) in controls and patients with Parkinson's disease (without medication) and patients with Huntington's chorea. Age distribution.

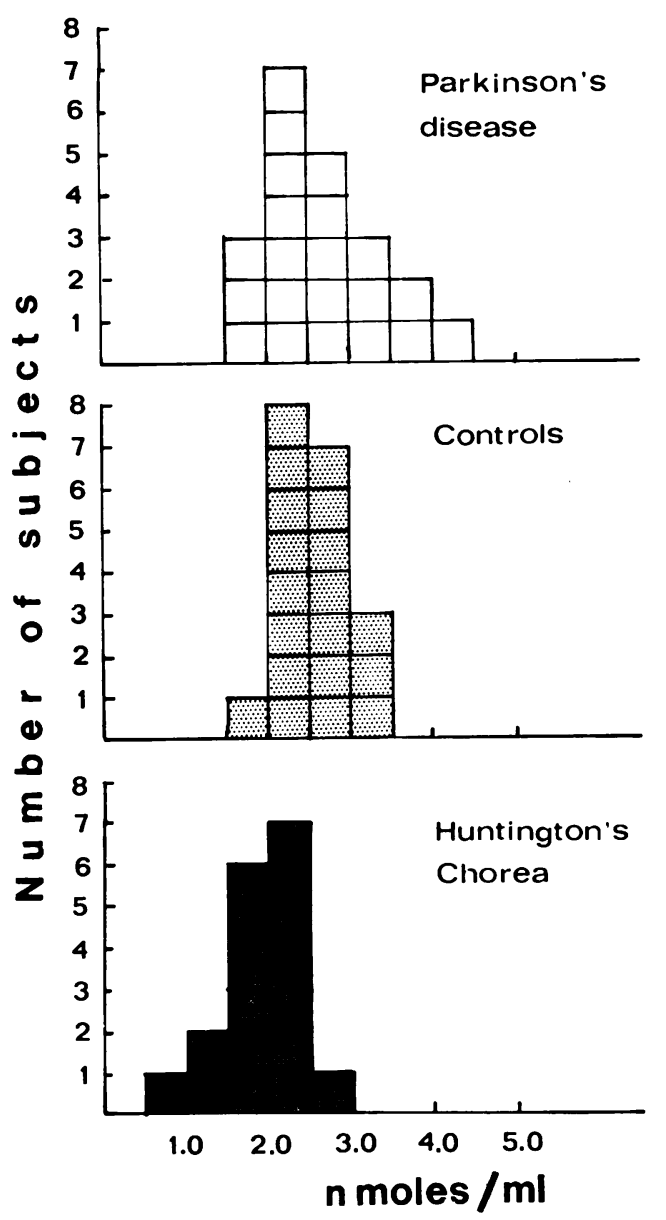

FIG. 6. Frequency of lumbar CSF Ch values (n-mole) ml.) in controls, Parkinson's disease, and Huntington's chorea.

centration of controls and patients with Huntington's chorea, a considerable overlapping between the materials exists (Fig. 5). This is also seen from the frequency distribution of values (Fig. 6).

As seen from Table 1 , the Ch concentration in ventricular CSF from patients with Parkinson's disease and intention tremor is somewhat higher than the lumbar CSF $\mathrm{Ch}$ concentration. Furthermore, in most of the ventricular CSF samples from the patients in Table 2, a higher $\mathrm{Ch}$ concentration than the mean lumbar concentration of the controls (Table 1) was found. The highest ventricular CSF $\mathrm{Ch}$ concentrations were found 
in cases with increased ventricular size and CSF pressure and in the case with an inflammatory process.

\section{DISCUSSION}

In the present investigation it has been shown that the lumbar CSF concentration of $\mathrm{Ch}$ is rather constant in man. Earlier reported values for human CSF, based on a small number of observations, range from $12-60 \mathrm{n}-\mathrm{mole} / \mathrm{ml}$. (Guggenheim and Löffler, 1916), to values of the same order as ours, $0 \cdot 5-2 \cdot 2 \mathrm{n}-\mathrm{mole} / \mathrm{ml}$. (Page and Schmidt, 1931) and 0.8-1.6 n-mole $/ \mathrm{ml}$. (Bowers, 1967). In these studies, bioassay determination of the ACh derived from the $\mathrm{Ch}$ in the sample, after non-enzymatic acetylation, was used. This involves treatment of the sample with acetic anhydride. Since CSF contains more than 7 n-mole/ml. choline phospholipids (Sastry and Stancer, 1968), this acetylation procedure may cause an in vitro increase of choline to be acetylated. In fact, Bowers (1967) reported different choline concentrations when acetylation was carried out with acetic anhydride before and after removal of proteins and phospholipids from the CSF. Using the enzymatic acetylation, no such difference in the choline concentration of the CSF was obtained (Schuberth and Sundwall, 1971). Furthermore, by enzymatic acetylation of CSF Ch with labelled acetyl-CoA, bioassay of $\mathrm{ACh}$ is avoided, which is advantageous, since bioassay procedures are not completely specific and the presence of drugs and modifying substances in the samples may interfere with the determination.

Several authors using bioassay have reported ACh-like activity in human lumbar CSF (Schain, 1960). Whether ACh is a normal constituent of human CSF or not, has, however, been a subject of controversy. Duvoisin and Dettbarn (1967), who added an acetylcholinesterase inhibitor to the sample immediately after lumbar puncture and performed appropriate controls to identify $\mathrm{ACh}$, found $\mathrm{ACh}$ in all samples examined. No conclusive difference in CSF ACh concentration was found between controls and patients suffering from different diseases, including Parkinsonism and chorea. They reported a mean $\mathrm{ACh}$ concentration in lumbar CSF from controls of $17 \mathrm{ng} / \mathrm{ml}$., which is about $4 \%$ of the mean lumbar CSF Ch con- centration found by us. It was noted in their study that CSF samples not treated by an acetylcholinesterase inhibitor showed only a very $\stackrel{\mathbb{D}}{\leftrightarrows}$ slow decline in $\mathrm{ACh}$ upon storage in room o temperature. This suggests that $\mathrm{ACh}$ entering CSF had been hydrolysed to values below an effective substrate concentration for the acetyl- $\stackrel{\text { SO }}{\stackrel{S}{2}}$ cholinesterase present in the CSF. In view of these findings, it seemed more fruitful to in- $\stackrel{\overrightarrow{0}}{\vec{*}}$ vestigate the CSF concentration of the $\mathrm{ACh}$ metabolite $\mathrm{Ch}$ in an attempt biochemically to evaluate cholinergic activity.

Our finding of lower lumbar CSF $\mathrm{Ch}$ in 흘 Huntington's chorea is interesting in view of the $\frac{\bar{c}}{\vec{D}}$ suggested cholinergic hypoactivity in the striatum $\stackrel{\varnothing}{\varrho}$ and stresses the need for further studies on $\mathrm{Ch} \stackrel{\text { ڤ }}{\circ}$ metabolism in this disorder (Aquilonius and $\overrightarrow{0}$ Sjöström, 1971). It is by no means certain, however, that a low lumbar CSF Ch concentration $\vec{\sigma}$ reflects altered $\mathrm{ACh}$ metabolism in the central nervous system. Choline in CSF can be derived from plasma $\mathrm{Ch}$, phospholipid metabolism and ACh being released from nervous tissue adjacent i to the lumbar subarachnoid space. The relatiE N proportions of these sources are not know $\vec{P}$. That the Ch concentration in CSF is not meref a reflection of plasma $\mathrm{Ch}$ concentration hass $\vec{O}$ earlier been demonstrated (Gardiner and Domer, 1968; Jönsson et al., 1969). If CSF G.9.8 concentration reflects, to a major part, phos pholipid metabolism, the low CSF Ch found Huntington's chorea might parallel the shrink-? age of nervous tissue as well as the reduction of phospholipids in particular reported in the disease (Borri, Opden Velde, Hooghwinkel, and Bruyn, 1967).

Although it is not known to what extent the $\mathrm{CSF} \mathrm{Ch}$ is derived from the brain $\mathrm{ACh}$, thereo are some data in favour of CSF $\mathrm{Ch}$ as a marker of central cholinergic activity. Oxotremorine, which decreases acetylcholine turnover in the brain (Schuberth, Sparf, and Sundwall, 1969) and which exerts its main effects on the struc-io tures around the lateral ventricles (Bartolini, Bartolini, and Pepeu, 1970; Campbell and $\delta$ Jenden, 1970), caused a decrease of $\mathrm{Ch}$ in the CSF from the lateral ventricle of the dog, while응 the $\mathrm{Ch}$ concentration in the cisternal CSFD remained unaltered (Aquilonius, Schuberth, and으․ Sundwall, 1970). Also, from the results of then amphetamine effect on CSF $\mathrm{Ch}$ in man, there is 
some evidence for a correlation between the $\mathrm{Ch}$ concentration in CSF and $\mathrm{ACh}$ turnover in the central nervous system. It has been shown that amphetamine causes an increased release of $\mathrm{ACh}$ from exposed cortex of experimental animals (Beani, Bianchi, Santinoceto, and Marchetti, 1968). In accordance with this, it was found that the $\mathrm{Ch}$ concentration of lumbar spinal fluid from amphetamine addicts was significantly higher during intoxication than after detoxication (Jönsson et al., 1969).

If a major part of CSF $\mathrm{Ch}$ is derived from $\mathrm{ACh}$ hydrolysis in brain regions adjacent to $\mathrm{CSF}$, an increased $\mathrm{Ch}$ concentration should be suspected in Parkinson's disease, where a cholinergic overactivity in striatum is likely. The failure to find an increased $\mathrm{Ch}$ concentration in lumbar CSF could however be due to the efficient removal of $\mathrm{Ch}$ from $\mathrm{CSF}$ during the ventriculocisternal passage (Aquilonius and Winbladh, 1971). For this reason, we studied ventricular and lumbar CSF $\mathrm{Ch}$ in five patients with Parkinson's disease undergoing ventriculography. The mean value of ventricular CSF $\mathrm{Ch}$ concentration $(3 \cdot 2 \pm 0 \cdot 23 \mathrm{n}-\mathrm{mol} / \mathrm{ml}$.) was higher than in lumbar CSF $(2 \cdot 6 \pm 0 \cdot 19 \mathrm{n}-\mathrm{mole} / \mathrm{ml}$.). In five patients with intention tremor, however, the ventricular CSF $\mathrm{Ch}$ concentration was even somewhat higher $(3.7 \pm 0.45 \mathrm{n}$-mole $/ \mathrm{ml}$. $)$ than in the Parkinsonism group. Conclusions are, however, hard to draw from this comparison as nothing is known about central cholinergic mechanism in intention tremor. For obvious reasons, no satisfactory control material of ventricular CSF could be obtained and the wide variation of ventricular $\mathrm{CSF} \mathrm{Ch}$ concentration in the group consisting mainly of brain tumour cases with increased CSF pressure makes comparison with this material useless.

\section{REFERENCES}

Aquilonius, S.-M., and Tiselius, P. (1969). Measurement of rigidity and tremor in Parkinson's disease. Acta Neurologica Scandinavica, 45, 327-334.

Aquilonius, S.-M., Schuberth, J., and Sundwall, A. (1970). Studies on choline in cerebrospinal fluid. Acta Pharmacologica and Toxicologica, 28, Suppl. 1, 35.

Aquilonius, S.M-., and Sjöström, R. (1971). Cholinergic and dopaminergic mechanisms in Huntington's chorea. Life Sciences, Part 1, 10, 405-414.

Aquilonius, S.-M., and Winbladh, B. (1971). Cerebrospinal fluid clearance of choline. Acta Pharmacologica et Toxicologica, 29, Suppl. 4, 64.

Aquilonius, S.-M., Nyström, B., Schuberth, J., and Sundwall, A. (1971). Cerebrospinal fluid choline in extrapyramidal diseases. Acta Pharmacologica et Toxicologica, 29, Suppl. $4,3$.

Bartolini, A., Bartolini, R., and Pepeu, G. C. (1970). The effect of oxotremorine on the acetylcholine content of different parts of cat brain. Journal of Pharmacy and Pharmacology, 22, 59-60.

Beani, L., Bianchi, C., Santinoceto, L., and Marchetti, P. (1968). The cerebral acetylcholine release in conscious rabbits with semi-permanently implanted epidural cups. International Journal of Neuropharmacology, 7, 469-481.

Borri, P. F., Opden Velde, W. M., Hooghwinkel, G. J. M., and Bruyn, G. W. (1967). Biochemical studies in Huntington's chorea. VI. Composition of striatal neutral lipids, phospholipids, glycolipids, fatty acids, and amino acids. Neurology (Minneap), 17, 172-178.

Bowers, M. B. Jr., (1967). Choline in cerebrospinal fluid. Life Sciences, Part 2, 6, 1927-1933.

Calne, D. B. (1970). Parkinsonism: Physiology, Pharmacology and Treatment. Arnold: London.

Campbell, L. B., and Jenden, D. J. (1970). Gas chromatographic evaluation of the influence of oxotremorine upon the regional distribution of acetylcholine in rat brain. Journal of Neurochemistry, 17, 1697-1699.

Dvoisin, R. C., and Dettbarn, W.-D. (1967). Cerebrospinal fluid acetylcholine in man. Neurology (Minneap.), 17, 1077-1081.

Ehringer, H., and Hornykiewicz, O. (1960). Verteilung von Noradrenalin und Dopamin (3-Hydroxytyramin) im Gehirn des Menschen und ihr Verhalten bei Erkrankungen des extrapyramidalen Systems. Klinische Wochenschrift, 38, 1236-1239.

Gardiner, J. E., and Domer, F. R. (1968). Movement of choline between the blood and cerebrospinal fluid in the cat. Archives Internationales de Pharmacodynamie et de Thérapie, 175, 482-496.

Guggenheim, M., and Löffler, W. (1916). Über das Vorkommen und Schicksal des Cholins im Tierkörper. Eine Methode zum Nachweis kleiner Cholinmengen. Biochemische Zeitschrift, 74, 208-218.

Guldberg, H. C., Turner, J. W., Hanieh, A., Ashcroft, G. W., Crawford, T. B. B., Perry, W. L. M., and Gillingham, F. J. (1967). On the occurrence of homovanillic acid and 5hydroxyindol-3-ylacetic acid in the ventricular C.S.F. from patients suffering from Parkinsonism. Confinia Neurologica, 29, 73-77.

Johansson, B., and Roos, B.-E. (1967). 5-hydroxyindoleacetic and homovanillic acid levels in the cerebrospinal fluid of healthy volunteers and patients with Parkinson's syndrome. Life Sciences, Part 1, 6, 1449-1454.

Jönsson, L.-E., Schuberth, J., and Sundwall, A. (1969). Amphetamine effect on the choline concentration of human cerebrospinal fluid. Life Sciences, Part 1, 8, 977981.

Page, I. H., and Schmidt, E. (1931). Über die Abspaltbarkeit des Cholins aus Lecithin und den Cholingehalt der Cerebrospinalflüssigkeit. Hoppe-Seylers Zeitschrift für physiologische Chemie, 199, 1-9.

Sastry, P. S., and Stancer, H. C. (1968). Quantitative analysis and fatty acid composition of phospholipid constituents in cerebrospinal fluid of various age groups. Clinica Chimica Acta, 22, 301-307.

Schain, R. J. (1960). Neurohumors and other pharmacologically active substances in cerebrospinal fluid: A review of the literature. Yale Journal of Biology and Medicine, 33, 15-36.

Schuberth, J., Sparf, B., and Sundwall, A. (1969). A technique for the study of acetylcholine turnover in mouse brain in vivo. Journal of Neurochemistry, 16, 695-700.

Schuberth, J., and Sundwall, A. (1972). A method for the determination of choline in body fluids. (To be published.) 